Дејан Микавица

Универзитет у Новом Саду

Филозофски факултет

Одсек за историју

mikavica@ff.uns.ac.rs
Оригинални научни рад

примљено: 30. јун 2011

прихваћено: 1. октобар 2011

\title{
МИЛЕТИЋЕВЦИ НА ПУТУ ФОРМИРАЊА СТРАНКЕ 1860-1869*
}

Сажетак: Присталице и следбеници Милетићеве иделогије су у деветогодишњем периоду обновљеног парламентарно-политичког живота (1860-1869) настојали да у оквиру различитих омладинских, културно-просветних и национално-политичких удружења, установа и организација оснаже претпоставке за остварење националних и демократских циљева српског народа у Хабзбуршкој монархији. Свестрано прихватајући тековине европских либералних покрета, милетићевци су успели да српску националну политику, после укидања апсолутистичког режима, дефинишу на другачији, напреднији, либералнодемократски начин и тако увећају изгледе за целовит друштвени и духовни препород народа који су представљали. У борби против владајуће доктрине политичке неравноправности грађана и народа на ширем простору Угарске нису успели да осигурају подршку и савезништво мађарских и хрватских либерала, док је у области српске црквено-просветне аутономије интензивирано њихово сучељавање са конзервативно-клерикалним представницима црквене јерархије. Упркос томе, прогресивно су утицали на све области друштвеног живота пречанских Срба, свестрано допринели оснивању и активностима Уједињене омладине српске и најзад основали Странку која је пред собом имала изузетан задатак, да заступа интересе свих Срба у Аустроугарској и утиче на државну и националну политику Србије и Црне Горе.

Кључне речи: Светозар Милетић, Матица српска, Источно питање, Уједињена омладина српска, Угарски сабор, Српски црквено-народни сабор, Срби, Хрвати, Мађари, Војводина.

Ближу предисторију Српске народне слободоумне странке употпунило је деловање новообновљених српских академских дружина и њихово обједињавање у оквиру Уједињене омладине српске, која је баштинила тековине европске грађанске револуције, српску духовну и државотворну традицију и национално-политичку мисао црвених и световних првака пречанских Срба дефинисану на Црквенонародним саборима од краја XVII века. Идеологији Милетићеве странке се у литератури, са извесном историјском оправданошћу, аналогно тражи исходиште у 
Текелијиној политици на Темишварском сабору 1790, демократско и национално одређење у ратном искуству 1848-1849, ${ }^{1}$ друштвено упориште у економски ојачалом српском грађанству, ${ }^{2}$ а писано програмско утемељење у Туциинданском чланку који је, као одговор на царско решење о укидању Војводства Србије, написао и објавио у Србском дневнику првак српских либерала, тридесетчетворогодишњи Светозар Милетић. ${ }^{3}$ Овим чланком оспорена је сврсисходност дотадашње српске лојалности Бечком двору, а Милетић, тада већ харизматични предводник српског грађанства и народни трибун, јасно се одредио према аустрофилству српске црквене јерархије, према питању Српске Војводине и према мађарској либералној политици у Хабзбуршкој монархији. ${ }^{4}$ Подсећајући да је Бахово Војводство укинуто, дефинисао је критичан став према политици Бечког двора напоменувши да на њу пречански Срби убудуће не могу и не смеју рачунати. Указао је да је са пропашћу Војводства још нешто „сахрањено”, нешто што никад више неће моћи васкрснути, јасно алудирајући на традиционално српско поверење, ослонац и сарадњу са владарима хабзбуршке династије. Старим путем више се није могло, по Милетићевом суду, и због тога је сматрао да је дошло време да се закључе рачуни „с досадашњом владом". Формалном оградом, која је пратила ову мисао, задржао је легитимни оквир свог политичког става: „Ту као уставни људи не мешамо цара и краља, који је свет и неодговоран, него владу аустријску”. Суштински одбацујући потребу политичке сарадње Срба са Бечким двором, Милетић није одбацио историјско-привилегијална права ${ }^{5}$ односно право позивања на привилегије које је српском народу за војне заслуге давао и потврђивао аустријски цар од краја XVII века. ${ }^{6}$ Српско Војводство дефинисао је као „биће политично народа српског с ове стране”, верујући да ће оно „у прображеном виду, ма и без имена тога зацело васкрснути”. Свестан историјског значаја који је имала Војводина као националнополитички програм српског народа у Хабзбуршкој монархији није намеравао да га

\footnotetext{
* Рад је настао као фазни резултат републичког пројекта број 177002 под називом Војвођански простор $у$ контексту европске историје.

${ }^{1}$ С. Гавриловић, Политичка борба за Српску Војводину у Аустријској иаревини 1848-1918, зборник радова Српски покрет у револуцији 1848-1849, Нови Сад 2000, 7-31.

${ }^{2}$ Н. Петровић, Светозар Милетић и Народна странка, књ. 1, Сремски Карловци 1968, 2.

${ }^{3}$ С. Милетић, Сабрани списи, књ. 1, Београд 1999, 232-234.

${ }^{4}$ Д. М. Ковачевић, Светозар Милетић, живот и политика, Београд 2009, 40-41.

${ }^{5}$ В. Гавриловић, Дипломатички списи код Срба у Хабзбуршкој монархији и Карловачкој митрополији од краја XVII до средине XIX века, Ветерник 2001; Д. Микавица, В. Гавриловић, Г. Васин, Знаменита документа за историју Срба 1538-1918, Нови Сад 2007, 13-25.

${ }^{6}$ У књижевној и историографској литератури често је мишљење да су национални и политички захтеви Срба у Аустрији и Угарској увек имали привилегије као једино легитимно упориште: „Борба Срба у Угарској за национални опстанак базираше се на једном застарелом привилегијалном праву, на које су аустријски цареви радо заборављали, а одговорне владе игнорисале па чак и презирале. Сталним и вештим маневрисањем са тим својим привилегијалним правом на црквно-политичком терену, они су са питањима уређења своје Цркве, како на својим црквеним саборима, тако и у државном сабору били у прилици, да су поред ствари, које се беху односиле на Цркву, могли да стављају на дневни ред и своја национално - политичка питања и да њима обрате пажњу на своја права и националне потребе” (М. Томандл, Светислав Касапиновић, Панчево 1940, 16).
} 
одбаци нити да, после укидања Круновине, одбије од себе заговорнике и присталице идеје српске политичко-територијалне аутономије као једине поуздане гаранције очувања српског националног идентитета у држави у којој нису имали статус равноправног политичког народа. Због тога је писао како је „Војводство у Бечу и Пешти сарањено", али не и „у срцима честитих Србаља”, да не треба жалити због нестанка „Баховог Војводства”, али и да не постоје разлози за радост због његовог укидања: „Војводство је сарањено - али ми му нисмо „очи заклопили, и злосретан би Србин био, који би неверном ногом ковчегу Војводства приступио ма и само да га целива, а камоли да ликује". ${ }^{7}$

Своје виђење нове Војводовине Српске, прижељкиване на принципу национално заокружених угарских жупанија, првенствено Бачко-бодрошке и Торонталске (Банатске), са надлежностима које су понекад подсећале на суверенитет швајцарских кантона, бранио је, кад год су за то постојали услови, свим расположивим политичким средствима, одушевљено подржаван од стране својих бројних присталица, на Благовештенском сабору и после њега, у преданом и пожртвованом двадесетогодишњем нестраначком и страначком деловању, у новинским чланцима и полемикама, на скуповима, у надахнутим, аргументованим, провокативним и визионарским беседама на Угарском, Хрватском и српском Црквено-народном сабору. ${ }^{8}$ У овом духу су пречански либерали, углавном његови истомишљеници и следбеници, настојали да осмисле српску националну политику, да Војводину представе као административно решење које не противречи идеји мађарског државног суверенитета и концепту федералног дуализма као битне саставнице очекиваног аустријско-мађарског споразума. О предусретљивости милетићевих либерала и спремности на попуштање мађарској страни, посебно сведочи њихова уздржаност у посланичком иступању коју су морали запазити сви који су пратили рад Угарског сабора $1861 .^{9}$ Шмерлингову политику су, често неоправдано, оцењивали неискреном и неспремном да српским захтевима, после укидања Војводства Србије, на било који начин изађе у сусрет. ${ }^{10}$ Михаило Полит Десанчић, Милетићев ученик, најискренији следбеник и најистрајнији политички присталица, веровао је да све зависи управо од овог аустријског државног министра али да он једноставно „нема одважности да сазове српски политички сабор у тој цели, да успостави Војводину па да та Војводина шаље посланике у рајхсрат бечки", већ да се „ограничио само на то да сазове српски сабор на ту цел (Благовештенски сабор - Д. М.), да се посаветује о гаранцијама за српску народност у бившој Војводини према изреченом утеловљењу у Угарску". ${ }^{11}$ Другачије мишљење нису имали ни други милетићевци, угледни представници српског либералног грађанства, еминентни интелектуалци, јавни и књижевни радници из Милетићевог

\footnotetext{
${ }^{7}$ С. Милетић, Сабрани списи, књ. 1, 232.

${ }^{8}$ Д. Микавица, Политичка идеологија Светозара Милетића, Нови Сад 2006, 35-37, 100,

${ }^{9}$ Az 1861-dik évi april 2-ikara hirdetett orszaggyulés képviselohazanak naploja, I-II, Pest 1861; Д. М. Ковачевић, Јаков Игњатовић, Београд 2006, 87-90; Србски дневник, 1861, бр. 25, 29, 33, 42, 43.

${ }^{10}$ Д. Микавица, Српско питање на Угарском сабору 1690-1918, Нови Сад 2011, 116-117.

${ }^{11}$ Михаило Полит Десанчић, Све досадашње беседе, књ. 1, Нови Сад 1889, 10.
} 
круга. Њихова очекивања грађена су на уверењу да су Мађари спремни да, после трагичних искустава из српско-мађарског рата, прихвате Србе као равноправан народ, озаконе њихова политичка права, да им осигурају гаранције за несметан развој и очување националног идентитета у Угарској. У том погледу су предњачили Петар Чарнојевић и Јаков Игњатовић. Јован Суботић је сазивање српског Сабора 1861. видео само као маневар Беча против мађарске владе у Пешти, барон Јован Живковић показивао је отворену наклоност према мађарској страни, ${ }^{12}$ Јаков Игњатовић је мађарске законе из 1848. представљао као повољније решење за Србе него што је била Бахова управа у Војводству Србији од $1849,{ }^{13}$ Стеван Павловић је био уверен да ће Угарски сабор уважити српска права и осигурати српску народност, ${ }^{14}$ док је Петар Чарнојевић пред српским Сабором 1861. предочио да као свој најбитнији задатак сматра „народно благостање у савезу и љубави с Мађарима". ${ }^{15}$ Званична Србија подржавала је оваква гледишта упућујући пречанске Србе да траже аутономију српске народности у Угарској али и да мађарске законе из 1848. прихвате као гаранцију слободе и напретка. ${ }^{16}$ Није изостало ни еуфорично „кафанско братимљење" Срба и Мађара у којем је демонстрирана спремност да се постигне, до тада незамисливо у српском политичком искуству, братско савезништво два народа, српског који је представљао Милетић и мађарског који су предводили првенствено Деак и Андраши. Овај ентузијазам је достигао врхунац на прослави стогодишњице Текелијиног рођења ${ }^{17}$ на којој су емотивно евоцирана сећања на његов говор на српском Сабору $1790^{18}$, неумерено уздизано српскомађарско пријатељство ${ }^{19}$, декламовани стихови посвећени Текелији, уприличена

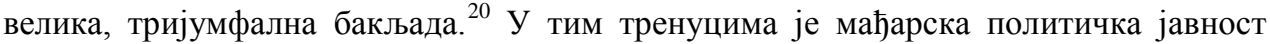
усмеравана у духу одушевљене подршке Србима који су показивали спремност да

\footnotetext{
12 Ј. Суботић, Автобиографија, трећи део: Лето, Нови Сад 2009, 134, 142.

${ }^{13}$ Србски дневник, 22. јануар 1861, бр. 7.

${ }^{14}$ Србски дневник, 9. март 1861, бр. 20.

${ }^{15}$ Н. Петровић, Светозар Милетић и Народна странка, књ. 1, 98.

${ }^{16}$ Србски дневник, 19. март 1861, бр. 23.

17 Матица српска је преузела на себе организацију ове прославе. Јован Ђорђевић је, по угледу на мађарско обележавање стогодишњице њиховог реформатора Ференца Казинција, изнео у Србском дневнику још у новембру 1859. предлог да се оваква свечаност одржи. На спровођењу овог предлога ангажовали су се у други милетићевци, пре свих Антоније Хаџић, тада секретар Матице српске, Павле Којић, њен председник, владика бачки Платон Атанацковић. Матица српска је предлог прихватила крајем априла 1860, а свечаност је одржана 29. августа 1861. у Новом Саду.

${ }_{18}^{18}$ В. Гавриловић, Темишварски сабор и Илирска дворска канцеларија 1790-1792, Нови Сад 2005, 131-147.

${ }^{19}$ Поједини српски посланици из Милетићевог круга брзо су губили популарност код својих сународника јер нису умели да пронађу прихватљиву меру у залагању за српско-мађарско савезништво. Посебно је Петар Чарнојевић осуђиван због „безусловног пристајања уз Мађарску" (Н. Петровић, Светозар Милетић и Народна странка, књ. 1, 165).

${ }^{20}$ Б. Ковачек, Јован Ђорђевић, Нови Сад 1964, 187-190; Исти, Текелијанумске историје, Нови Сад 1997, 91-102; Д. М. Ковачевић, Светозар Милетић, 49-50; Б. Бешлин, Европски утицаји на српски либерализам, 407-408.
} 
се одрекну сваке сарадње са Бечким двором и националне интересе потпуно подреде договору са мађарском страном. ${ }^{21}$

Другу упоришну тачку програма Милетићевих либерала представљало је решење Источног питања, онако како је уобличено у низу новинских чланака, а нарочито у Политовој расправи Die Orientalische Frage und ihre organische Lösung, ${ }^{22}$ и Милетићевој студији Источно питање објављеној $1863^{23}$. У њима је предочено да се од српских кнежевина, Србије и Црне Горе, очекује одлучна и јединствена национална и спољна политика у циљу стварања самосталне српске државе (,веће Србије") ${ }^{24}$ која би обухватала Србију, Босну, Херцеговину, Црну Гору, Стару Србију и један део Македоније. ${ }^{25}$ Политичка гледишта Милетића и његових сабораца и следбеника према другим значајним политичким питањима у деценији која је претходила Бечкеречкој конференцији 1869. исказивана су највише у Србском дневнику од 1861. до 1864. и у Застави која је почела да излази у Пешти 1866. Управо око ових листова створено је језгро из којег ће касније нићи, формално прва српска страначка политичка организација, Српска народна слободоумна странка. ${ }^{26}$ Пишући и објављујући чланке и студије и активно се одређући према актуелним дневно-политичким темама, милетићевци су профилисали погледе према кључним националним питањима и неколико година касније спонтано их преточили у писани страначки програм. ${ }^{27}$ Према хрватским политичким опцијама, задржали су критички став, посебно када се у хрватској јавности и на Хрватском сабору инсистирало на томе да Срби немају право на политичку посебност на простору Хрватске и Славоније. Страначку политику Штросмајера, Рачког и Мразовића, оцењивали су, у ово време, као „великохрватску", искључиву према српским интересима у Војној граници и Срему и усмерену ка стварању велике, етнички и политички јединствене,

${ }^{21}$ Т. Пал, Мађарска политичка јавност и српско питање на Балкану 1860-1878, Нови Сад 2001, 82-83.

${ }^{22}$ Источно питање у Политовој политичкој идеологији заузима централно место од 1857. године, када је објавио прве чланке о њему у новосадском листу Србски дневник (бр. 44-47). После 1857 године, Полит је објављивао чланке о Источном питању у чувеном листу Allgemeine Zeitung (1860-61), а касније и у бечким листовима Ost und West, штутгартским Detsche Vierteljahrsschirft, париским Revue dex deux Mondes, лајпцишким Unsere Zeit, минхенским Münchener Zeitung, да би се истој проблематици вратио у Србском дневнику (1861), с надом да ће најзад „сунце са истока и Србство озарити” и да ће се ,,једаред Срби при решавању источног питања ујединити и Србство ону важност у Европи добити која Србима по повесници и по народном карактеру приличи”.

${ }^{23}$ Битнија разлика између ова два списа запажа се у томе што је, у контексту стварања балканских држава уместо Османског царства, Милетић сматрао да Солун треба да припадне Србији, док је за Полита Солун требало да буде неутралан град.

${ }^{24}$ С. Милетић, Сабрани списи, књ. 2/1, 155.

${ }^{25}$ Д. Микавица, Михаило Полит Десанчић, вођа српских либерала у Аустроугарској, Нови Сад 2007, 135.

${ }^{26}$ В. Крестић, Историја српске штампе у Угарској 1791-1914, Нови Сад 1980, 144, 150, 151-194.

${ }^{27}$ И у листовима који нису делили Милетићева гледишта, као што су били Србобран и Напредак, објављивани су чланци који су указивали на подударност када је реч о многим актуелним питањима. Федерализам на националној основи заговарао је и Напредак (1863), за српски језик као службени и на Угарском сабору, за српску аутономну област као и против хрватских национално-политичких концепција иступао је и Србобран (1861-1864). Разлике су, међутим, биле очигледне у односу на политику Бечког двора, значају српске црквене јерархије, односу према мађарским либералима (В. Крестић, Историја српске штампе у Угарској 1791-1914, 158-159, 170-171). 
католичке Хрватске. ${ }^{28}$ Милетић и његове присталице су на Хрватском сабору 1861. пристајали уз Уставно-народну странку као странку која је, за разлику од хрватских либерала окупљених у Народно-либералној странци, показивала спремност да српске национално-политичке захтеве узме у обзир. Као посланик на Хрватском сабору 1866. Милетић је говорио у прилог политичке посебности српског народа у Хрватској и у Застави објавио захтеве српског народа у Хрватској који су се сводили на равноправност српског народа са хрватским у свим културним, верским и политичким аспектима. На тај начин је учврстио захтеве Срба да им се правнополитички статус у Хрватској уреди на тамошњем сабору одговарајућом законском регулативом. $^{29}$

У српским културно-просветним и црквено-народним установама милетићевци су стицали превласт осам година пре него што је Српска народна слободумна странка формално основана. У Матици српској постигли су значајан утицај већ 1861. када је Милетић израдио нацрт Устава за ову установу ${ }^{30}$, превагу су остварили три године касније када је она пресељена у Нови Сад, а потпуну домининацију 1867. године. ${ }^{31}$ Не чело Матичиног Књижевног одељења Милетић биран је четири пута, од 1864. до 1867. и већину у овом одељењу одржавале су његове присталице ${ }^{32}$. Убрзо после Милетићевог избора на положај градског начелника Новог Сада 1861. године ${ }^{33}$, уследио је и његов долазак на чело Српске читаонице у оквиру које је, првенствено његовим и Ђорђевићевим залагањем, основан Одбор за Српско народно позориште и тако осигуране претпоставке за деловање још једне установе од изузетног националног значаја. Да је Нови Сад већ 1861. постао „тврђава за одбрану српске народности" потврђено је и одлуком градске скупштине којом се српски језик уводи као службени језик. ${ }^{34}$ И у књижевним кафанама, у којима је преовладавало у то време либерално расположење и национални романтизам, окупљали су се Милетићеви политички истомишљеници, уважени писци, уметници и јавни радници, често водећи важне политичке разговоре, размењујући мишљења о деловању у прилог српских националних интереса, одржавајући чувене здравице, утичући на атмосферу, јавно мнење и

\footnotetext{
${ }^{28}$ С. Милетић, Сабрани списи, књ. 1, 211-213; књ. 2/1, 102-104, 303-310; књ. 3, 378-380.

${ }^{29}$ Д. Микавица, Политичка идеологија Светозара Милетића, 107; Д. Микавица, В. Гавриловић, Г. Васин, Знаменита документа за историју Срба 1538-1918, 268-269, 291-292.

${ }^{30}$ До тада је важио Устав написан још 1826. године.

31 Ж. Милисавац, Историја Матице српске 1826-1864, књ. 1, Нови Сад 1986, 887-909; Б. Бешлин, Европски утииаји на српски либерализам, Нови Сад 2005, 524

32 Јован Ђорђевић, Јован Андрејевић Јолес, Ђорђе Натошевић, Ђура Вукичевић, Глигорије Гига Гершић, Антоније Хаџић, Лаза Костић, Јован Јовановић Змај, Ђура Даничић.

33 Јаков Игњатовић је изабран за главног бележника, а Јован Јовановић Змај за првог подбележника. Милетић је други пут изабран за градског начелника 1867, за великог бележника Лаза Костић, за почасног великог бележника Антоније Хаџић, а за великог подбележника Коста Трифковић.

${ }^{34}$ Д. М. Ковачевић, Светозар Милетић, 41.
} 
народно самопоуздање. ${ }^{35}$ Успон милетићеваца у српској средину су с посебно великом забринутошћу пратили владини чиновници. ${ }^{36}$

На српском Благовештенском сабору либерално опредељени српски прваци настојали су да прецизно и сагласно духу времена дефинишу националне и демократске захтеве српског народа и да се уверљиво представе као легитимни заступници целокупне српске политике, северно од Саве и Дунава. ${ }^{37}$ Међутим, на овом сабору, сазваном после укидања Војводства Србије, они су остали у мањини иако се њихова гледишта нису суштински разликовала од мишљења већине предвођене патријархом Јосифом Рајачићем и Ђорђом Стојаковићем који су успели да придобију посланике да гласају за одлуке које су се сводиле на стицање, уз подршку и сагласност Бечког двора, посебне српске територије, Српске Војводине, која би захватала Срем, Бачку, Банат и Војну границу, са самосталном политичком и управном организацијом, на челу са војводом, обласном скупштином, српским језиком са ћирилицом као службеним језиком, грбом са четири оцила, црвеноплаво-белом заставом. ${ }^{38}$ На траженом простору Срби би чинили приближно половину становништва. У овом погледу милетићевци нису имали битно другачије мишљење, али су ипак предлагали корекције одређених саборских решења како би изгледе за придобијање мађарске стране учинили реалнијим. ${ }^{39}$ На црквенонародним саборима, после 1861. Милетићеве присталице, у које убрајамо и световне и црквене представнике ${ }^{40}$, покушавале су остваре политичке и националне резултате у духу већинског расположења пречанских Срба, сагласно мађарофилској опцији владе кнеза Михаила и формално необавезујућој либерално-демократској политици мађарске политичке елите. Постизање ових циљева подразумевало је постизање превласти у вођењу националне политике и просветно-школске аутономије пречанских Срба из руку већинског дела српске православне црквене

35 Многе од тих састанака, посебно у „Белој Лађи" и „Код Камиле" будно су пратили полицијски доушници (Н. Петровић, Светозар Милетић и Народна странка, књ. 1, 215, 477-479).

${ }^{36}$ Аст Фердинанд, у функцији владиног комесара у Новом Саду, извештавао је мађарског министра унутрашњих послова да је Милетић ,, у срећној ситуацији стекао огроман утицај и на Матицу српску, Текелијанум, Јовановићеву задужбину, овдашњу српску црквену општину и на Удружење Срба занатлија". Даље је у извештају навео: „велики број појединаца, из материјалних разлога везаних за ове установе, фондове и удружења, окупља се под барјаком његове опасне политике из личног интереса. Њена два битна фактора представљају српска Омладина склона необузданости, која га слепо слуша, затим нижа и најнижа класа српског становништва коју је он завео и која чини ону опасну масу с којом Милетић безусловно располаже, користећи њу за своју агитацију на социјалном пољу против мађарске државе и која се раширила не само у граду и околини него чак и у Војној граници..." (Н. Петровић, Светозар Милетић и Народна странка, књ. 1, 490).

${ }^{37}$ Д. Микавица, Српско питање на Угарском сабору 1690-1918, Нови Сад 2011, 129-132.

${ }^{38}$ Србски дневник, бр. 31.

${ }^{39}$ Милетић и његове присталице су предлагале, за разлику од већине, да се посланици (24) за Угарски сабор бирају по угарским срезовима а да само два члана буду делегирана из Војводине, да из граница Војводине буду искључени Ада, Сента, Стара Кањижа и Мартонош, да војводу Војводине бирају сви грађани Војводине (Д. Микавица, Политичка идеологија Светозара Милетића, 38-40).

${ }^{40}$ У њих убрајамо првенствено Јована Суботића, Лазу Костића, Стевана Павловића, Александра Сандића, Јована Ђорђевића, Васу Ђурђевића, владику Платона Атанацковића, проте Бранковића, Јову Јовановића и друге. 
јерархије. На српском Илинданском сабору 1864. разлике између конзервативноклерикалне и либерално-демократске струје манифестовале су се највише у избору митрополита-патријарха, где је „Милетићева странка" ${ }^{41}$ желела да види Платона Атанацковића, затим у питању приоритета којим би Сабор требало да се бави: да ли да најпре уреди аутономне установе (школе, фондове, цркву) како су то мислили Милетићеви либерали или да се најпре изабере митрополит-патријарх, како је стајало у диктату царског комесара Јосипа Филиповића. ${ }^{42}$ Друго питање, које се односило на Румуне, решено је накнадно, 24. децембра формирањем Румунске митрополије. Изразита лојалност црквених великодостојника, пре свих изабраног (устајањем) митрополита-патријарха Самуила Маширевића и архимандрита Никанора Грујића била је посебан разлог незадовољства у редовима милетићевих присталица. На овом црквено-народном сабору, на којем је свештенство бирало 25 посланика, а број представника грађанства смањен са 50 на 25 док је 25 представника стизало из Границе, унапред је од стране владе осигурана доминација конзервативно-клерикалне струје. Она се очувала у следећих пет година. У овом периоду милетићевцима је преостало једино да критикују и осуђују црквену јерархију, притом неретко прелазећи границе уобичајено прихватљивог политичког неслагања. Сам Милетић је на Илиндански сабор отишао са речима „Идемо да поповима капу кројимо", док су други милетићевци ишли много даље од оваквих претњи. Тим пре што су се на наредном српском Црквено-народном сабору, одржаном после Нагодбе и неколико месеци после формирања Милетићеве Српске народне слободоумне странке, политичке разлике између Милетићевих либерала и конзервативаца показале као још непомирљивије. ${ }^{43}$ Неспоразуми су почели већ око позива митрополиту-патријарху да отвори српски Сабор јер су либерали били против овог обичаја. Сукоби су се појачали око попуњавања упражњених посланичких места ${ }^{44}$, имена Сабора ${ }^{45}$ и око избора председника Сабора ${ }^{46}$, а прекинути су тиме што су 34 нелиберална посланика напустили Сабор и тиме довели до његовог распуштања. И милетићевска и конзервативна страна у српском Црквено-народном сабору обратиле су се Јожефу Етвешу, мађарском министру

\footnotetext{
41 Тако су често називане присталице Светозара Милетића у конфидентским извештајима са српских Сабора. Употребљаване су и различите квалификације као замена њеном имену: „Озлоглашена Милетићева странка" итд. (Н. Петровић, Светозар Милетић и Народна странка, књ. 1, 490).

${ }^{42}$ Н. Петровић, Светозар Милетић и Народна странка, књ. 1, 238-240.

${ }^{43}$ Сабор је одржан у Карловцима од 1. јуна до 3. јула 1869 , био је расправног карактера и на њему се требало расправљати само око израде саборског устројства.

${ }_{44}^{44}$ Реч је о местима која су остала непопуњена после отцепљења Румуна.

${ }^{45}$ Милетић и његове присталице тражили су да се Сабор назове Српски народни сабор како би се тиме истакло да он представља национално представничко тело и како би му се тиме дао снажнији световнолиберални карактер.

${ }^{46}$ Милетићевци, иако у мањини, тражили су да се то место попуни избором, а не да се препусти, као до тада, митрополиту-патријарху.
} 
просвете. ${ }^{47}$ И поред свега тога, Милетић је пет година касније оценио да је већ на овом српском Сабору „народна свест славила свој морални тријумф". ${ }^{48}$

На Угарском сабору $1861 .^{49}$ политичко-парламентарно деловање милетићеваца видело се, поред поменутог ћутања српских посланика у прва три месеца саборског рада, највише у пледирању за постизање основних националних и грађанских права свих грађана и свих народа Угарске. Амандмани представника немађарских народа/народности, Румуна Сигисмунда Поповића и Србина Стефана Брановачког, ${ }^{50}$ о којима је решавано 10. јуна 1861, на 31. тачку Деаковог предлога која се односила на намеру да се задовоље народности, били су одбијени. Први је желео да се истакне спремност Сабора да се при задовољењу интереса народности иде до крајњих граница које не угрожавају интегритет Угарске, а други је истицао посебна историјска права Срба. Одбијањем амандмана који је предложио Имре

\footnotetext{
${ }^{47}$ Он је јавио патријарху да Сабор може да настави рад, али због Маширевићеве смрти (7. јануар 1870), он то није учинио, већ је ова дужност припала администратору Карловачке митрополије, будимском епископу Арсенију Стојковићу.

${ }^{48}$ Писао је у Застави, крајем септембра 1874: „Година 1869. на већ обележеном земљишту народне автономије доведе борбу хијерархије с народом у другу фазу. Заоштри противност међу противборним странама, и иза несрећног маневра 'бекства' са оствареног и једино за борбу оправданог земљишта, са Сабора, хијерархија би у отвореној борби и морално побеђена. Свест народна и спознање пута своме спасењу (подвукао Д. М.) славило је свој морални тријумф" (Сабрани списи, књ. 3, 214). Сасвим другачије је мислио Никанор Грујић. Он је записао следеће: „У тој жалосној расправи показало се, да су се скупили на тај конгрес понајвише јеретици или одпадници и безверци, којима није до вере ни до цркве, него им је до своје личне користи, коју траже за се на црквеном пољу, а да лакше могу доћи до ње, морају срушити власти црквене, и узети све госпотство и господарство у цркви у своје руке. Патријарх се изгубио у тој расправи са свијем. А они кад виде, да ту нема никаквога аукторитета, отму мах, па почну говорити противу Христа, противу Матере Божије, противу светаца и противу свега онога, на чему се оснива вера и црква православна. Ко је то слушао, а није био занешен тај није могао ни помислити да су се ту скупили људи једне вере и једне крви ... него је морао судити да су с ту скупили сами противници и непријатељи вере Христове и крви српске па хоће да се потуку с онима, који бране ту веру и ту крв српску..." (Н. Грујић, Автобиографија, Ср. Карловци 1907, 138). У Суботићевим мемоарима сукоб на Сабору 1869. приказан је без ових детаља (Ј. Суботић, Автобиографија, књ. 5, Нови Сад 1910, 9-35).

${ }^{49}$ Угарски сабор 1861. је радио у краљевској палати у Будиму од 2. априла до 22. августа и његов основни задатак је био да прими на знање промену на престолу, састави крунидбену повељу и да, у смислу Фебруарског патента, пошаље заступнике у Царевинско веће / Рајсхрат и на њему су формиране две мађарске странке, Странка адресе и Странка декрета/одлуке, назване по програмском опредељењу које се односило на политику према Бечу. Прва је, предвођена Ференцом Деаком, прихватала фактичко стање и била спремна да адресом тражи од владара уставно-територијалну реституцију, док је друга, предвођена Ласлом Телекијем, прихватала једино персоналну унију са Аустријом као облик државног уређења, Франца Јозефа није прихватала као наследника Фердинанада V образлажући то формално-правним и процедуралним разлозима и адресу је одбијала као начин обраћања тадашњем хабзбуршком владару. У суштини, обе странке су полазиле од „уставне самосталности" и „законске независности". Већину на Угарском сабору, на којем су били посланици бирани 1848, постигла је Странка адресе. Међутим, обе адресе које је упутио Угарски сабор 1861 (24. јун и 14. јул) биле су одбијене, за владара је била прихватљива једино реална унија Аустрије и Угарске, принципи Октобарске дипломе и Фебруарског патента, слање посланика у Царевинско веће. С обзиром да је Угарски сабор остао при ставу да треба вратити законе из 1848. и именовати мађарску владу, уследило је његово распуштање.

${ }^{50}$ Светозар Милетић се на овом Сабору одрекао посланичког мандата у његову корист.
} 
Иванка, ${ }^{51}$ да се разјасни појам интегритета отаџбине, потврђена је очигледна искључивост мађарских саборских посланика. И приликом претреса 40. тачке, која се бавила проблемом законског регулисања положаја народности, у третирању народносног питања остало се на принципу равноправности свих држављана Угарске без обзира на националност и вероисповест, с тим да је усвојен амандман, који је потекао од Ференца Деака, да се посебно истакне намера Сабора да још у истом сазиву задовољи претензије суграђана других народности „у свему, што се може остварити без политичког комадања земље и жртвовања њене законите независности". ${ }^{2}$ У двадесетседмочланој Комисији Угарског сабора, формираној за утврђивање начина решења народносног питања, било је свега три Србина, а од тога двојица милетићеваца - Петар Чарнојевић и Стефан Брановачки ${ }^{53}$, и они нису могли да онемогуће усвајање закључка да у Угарској постоји само једна политичка нација. ${ }^{54}$

У време Шмерлинговог провизоријума (1861-1865), мађарски либерални политички прваци показивали су начелну спремност да постигну договор са милетићевцима, али никакав конкретан политички договор није остварен. Мађарска политичка јавност је у то време будно пратила збивања на Балкану зазирући од свега што би могло личити на остварење идеје о „српском царству" уз помоћ Русије. На следећем Угарском сабору 1865-1869. ${ }^{55}$ српски либерали су превазишли предизборне несугласице ${ }^{56}$ и иступили јединствено, али у настојањима да учине саборску већину благонаклоном према национално-демократским тежњама балканских народа изнова су наишли на револт, непопустљивост и огорчење мађарске стране. Све интерпелације немађарских посланика, њихови предлози, резолуције које су се односиле на српско и народносно питање одбациване су и игнорисане. $^{57}$ Споразум Бечког двора и Угарског сабора 1867. донео је коначан сумрак настојању милетићеваца да се договоре са мађарским либералима у заједничком интересу, а народносно питање је сведено на општи принцип равноправности. Суочени са чињеницом да српска нација није у адреси Угарског сабора ни поменута, Светозар Милетић и Ђорђе Стратимировић су узалуд

\footnotetext{
${ }^{51}$ Имре Иванка (Imre Ivánka, 1818-1896), официр царске војске, посланик од 1865. до 1895, припадник опозиције, а затим владине странке.

${ }^{52}$ Mikó Imre, Nemzetisegi jog nemzetisegi politika, 98-99, 102-103.

${ }^{53}$ Уколико изузмемо као трећег Јакова Игњатовића. Председник Комисије био је барон Јожеф Етвеш.

${ }^{54}$ Д. Микавица, Српско питање на Угарском сабору, 124.

${ }^{55}$ Овај Сабор је радио од 14. децембра 1865. до избијања аустро-пруског рата 14. јуна 1866. Поново се састао 19. новембра 1866. и радио до средине 1869.

${ }^{56}$ Уочи избора за Угарски сабор већ је било извесно да Ђорђе Стратимировић представља озбиљног ривала Светозару Милетићу за вођство у српском либералном покрету, али су они ипак постигли договор да на изборима наступе заједно како би избегли поделу гласова српских бирача. Стратимировић и Милетић су били међу десет српских кандидата које је предложио Средишњи одбор. Стратимировићеве присталице су уочи постизања овог договора оспоравали Милетићу способност да успешно заступа српску политику на Угарском сабору објашњавајући то његовим недовољним знањем мађарског језика и због наводне неодмерености у политичким наступима.

${ }^{57}$ А. Лебл, Омладина и српско питање у пештанском Парламенту 1867-1871, зборник радова Уједињена омладина српска, Нови Сад 1968, 358.
} 
покушавали да макар поједине одредбе у адреси буду измењене. Нацрт народносног закона, који је подразумевао да се немађарским народима обезбеди равноправност језика, политичко-управна аутономија и арондација жупанија, потписан од стране 24 немађарска посланика, од тога осам Срба, предали су Сабору 11. фебруара 1867. Милетић, Брановачки и Мочоњи, али је он наишао на јединствену, оштру осуду мађарске посланичке већине. ${ }^{58}$

У години која је претходила постизању аустро-угарске нагодбе, милетићевци су у одлучујућој мери допринели организационом обједињавању младог српског нараштаја у оквиру Уједињене омладине српске. ${ }^{59}$ Ова националноромантичарска организација напредних просветитељских и либералнодемократских опредељења, усмерена ка буђењу српске националне свести, слављењу српске прошлости и проповедању словенске солидарности, имала је у тридесетрогодишњем Владимиру Јовановићу и четрдесетогодишњем Светозару Милетићу најпрепознатљивије вође, идеологе и узоре. ${ }^{60}$ у оквиру Омладине обједињена су сва кључна књижевна, културна и политичко-филозофска гледишта и национални потенцијали водећих српских омладинских трибуна, теоретичара и идеолога либералне оријентације. ${ }^{61}$ Осим јачања српске националне свести и учвршћивања духовног и културног заједништва Срба, омладинци су се ангажовали у објашњавању значаја образовања као претпоставке за привредни напредак друштва и материјално благостање грађана. У том правцу омладинска друштва су организовала јавна предавања, писала и преводила научну литературу, издавала календаре, држала „беседе" према омладинском задатку, потпомагала позоришну уметност, издавала и распростирала књиге, бринула о чистоти и правилности српског језика, јавном моралу и народној традицији. ${ }^{62}$ Најпознатија гесла Омладине била су „просветом до слободе" и „све на основу истине а с помоћу науке". ${ }^{63}$ Искуство и допринос милетићеваца у политичком деловању Омладине значило је пуно у осмишљавању будуће активности и дефинисању политичког програма Српске народне слободоумне странке, а многи проблеми у раду Омладине, често превазилажени управо захваљујући Милетићевим најближим сарадницима, послужили су као корисна поука у предстојећем страначком деловању. Ипак,

\footnotetext{
${ }^{58}$ Г. Васин, Национално-политичка борба Срба у Угарској 1848-1884, Истраживања 21, Нови Сад 2010, 326.

59 Уједињена омладина српска је основана у време када је био известан исход аустријско-пруског рата, као пандан сличним раније насталим организацијама у Италији и Немачкој, у дворани Српске гимназије где се окупило око 400 ђака, књижевника, политичара. Делокруг рада и устројство Омладине одређени су на основу предлога „брата Владимира". Руководство Омладине чинили су студенти, а председавајући прве скупштине био је Бранко Стефановић, председник бечке Зоре. Омладинска схватања ширена су у новинама и часописима Застава, Србија, Јединство, Млада Србадија, Вила, Матица, Јавор.

${ }^{60}$ Већ почетком августа 1866. је полиција у Будимпешти оцењивала да је Светозар Милетић „као главни заступник великосрпске идеје" у непосредном „споразуму са свим плановима српске омладине" (Н. Петровић, Светозар Милетић и Народна странка, књ. 1, 307-320).

${ }^{61}$ Д. Микавица, Лаза Костић, политичка биографија, Нови Сад 2011, 42-44.

62 Омладинска схватања ширена су у новинама и часописима Застава, Србија, Јединство, Млада Србадија, Вила, Матица, Јавор.

${ }^{63}$ J. Скерлић, Омладина и њена књижевност, Београд 1925, passim.
} 
демократски принцип у управљању Уједињеном омладином српском, јасно изражен у омладинским скупштинама ${ }^{64}$, чије су одлуке биле једино морално обавезујуће, константно несагласје у питању реда, дисциплине и организације често су представљали нерешив проблем. ${ }^{65}$

Највећи противници делатности Уједињене омладине српске били су исти они који су се одлучно, три године касније, свако из својих разлога, пратили, критиковали и прогонили странку милетићеваца - мађарска влада, аустроугарске државне службе и влада Кнежевине Србије. ${ }^{66}$ Слабљењу Уједињене омладине српске посебно је допринело њено унутрашње нејединство којем су умногоме допринели социјалистички оријентисани омладинци. У отпору њима истицали су се највише милетићевци који су и касније били у врху његове странке, Лаза Костић, Миша Димитријевић и други. ${ }^{67}$ Упркос честом несагласју у редовима Омладине, резултати њеног деловања примећивани су свугде где су живели Срби и у свим областима њиховог друштвеног и духовног живота, у Хабзбуршкој монархији и изван ње. На јавно мнење посебно су утицала предавања, текстови и публикације које су објављивали њени чланови. Омладинци су на виспрен, одважан, учен и аргументован начин разматрали кључна питања из области националног, политичког, образовног и културног живота. Отворено се дискутовало о потреби словенске узајамности, учешћу жена у омладинском покрету, увођењу дисциплине у омладинску организацију, о материјалном стању народа, државном уједињењу Срба, политичком и историјском значају српске православне цркве. До отвореног сукоба Уједињене омладине српске са кнезом Михаилом дошло је на другој омладинској скупштини у Београду ${ }^{68}$, када је Милетићу српска влада забранила прелазак, а затим полиција растерала омладинце због преовлађујућег критичког расположења према унутрашњим приликама у Кнежевини Србији и избора Јеврема Грујића за председника омладинске скупштине.

Против реалистичног критицизма у животу и политици, који је снажно изражен на четвртој скупштини Уједињене омладине, одважно и одлучно иступили су милетићевци романтичарских и леберално-демократских уверења. Актуелни сукоби либерала и клерикалаца на српским црквено-народним саборима нису

\footnotetext{
${ }^{64}$ Омладинске скупштине одржаване су једном годишње и било их је укупно шест од 1866. до 1871. Држане су у Новом Саду, Београду, Великом Бечкереку, Великој Кикинди, Новом Саду и Вршцу. Нису заседале по унапред прописаном пословнику, на њима су присуствовали и страни јавни и национални радници (Хрвати, Руси, Чеси Словенци), одржаване су и под ведрим небом као што је био случај у Београду и Кикинди и трајале су неколико дана.

65 У питању увођења реда и дисциплине у организацију Уједињене омладине није било сагласности. Чланови Зоре предлагали су увођење установе јавних укора у новинама за оне који не изврше дате обавезе, а социјалиста Живојин Жујовић се противио увођењу дисциплине. Устав Уједињене омладине српске није битније утицао на учвршћење њене организације. Ни један појединац није могао бити искључен из Омладине без одлуке двотрећинске већине на Скупштини и то на предлог најмање десет чланова. По Уставу, који је написао Светозар Милетић, одлуке Скупштине требао је да спроводи Годишњи одбор који се састојао од најмање пет чланова.

${ }^{66}$ В. Н. Кондратјева, Уједињена омладина српска и њено доба, Нови Сад 1977, 69-74.

${ }^{67}$ Д. Микавица, Лаза Костић, политичка биографија, 58-75, 83.

${ }^{68}$ Одржаној 6-8 августа 1867.
} 
остали изван интересовања омладинских скупштина. Омладинци су се на њима одређивали и према намесничком режиму у Србији, односу према тек основаној Српској народној слободоумној странци и називу посебног омладинског листа ${ }^{69}$. Иако није била довољно организационо осмишљена, Уједињена омладина је окупила бројне присталице и чланове, дефинисала свој Устав ${ }^{70}$, покренула листове и часописе, одушевљено заступала либерално-демократску идеологију у функцији српског националног ослобођења. Милетићевци и други омладинци у окриљу ове организације пронашли су простор за свестрано политичко ангажовање. Омладинци су као својеврсна странка, својим називом, политичком улогом, јавним и прикривеним националним и демократским деловањем, остављали утисак респектабилног политичког фактора. Мада је политика Уједињене омладине српске директно повезана са деловањем Милетићеве странке, није код свих омладинаца постојала сагласност у овом погледу. Владимир Јовановић је предводио оне чланове Омладине који били против мешања у страначку борбу. Они су остали у мањини насупрот већини која је стала на страну Милетићевих либерала $1869^{71}$. Аустријскомађарске државне власти и убудуће су будно пратиле рад Уједињене омладине, предузимале различите репресивне мере у циљу сузбијања и онемогућавања њеног политичког деловања сматрајући га деструктивним у односу на државну целовитост и расположење словенске јавности у целини. У време када су милетићевци припремали оснивачку конференцију Странке, чланови Омладине били су много даље од остварења својих национално-романтичарских уверења него три године раније, када је Уједињена омладина створена. Ипак, на путу формирања Странке, милетићевци су у Омладини имали јединог политички поузданог, природног савезника.

Српска народна слободоумна странка основана је с много мање омладинско-романтичарског одушевљења, а с много више рационалног политичког прагматизма који је подразумевао дисциплиновану и добро организовану парламентарну борбу за постизање грађанских права и осигурање националне једнакости свих народа у Угарској. Међутим, спознаја о неповољним друштвеноекономским и међународним околностима у тадашњој Европи, свест о стабилизацији дуалистичког поретка у Хабзбуршкој монархији и најзад Закон о народностима $^{72}$ и Закон о Црквено-школској аутономији, усвојени на Угарском сабору 1868. опомињали су милетићевце на могућност да ниједан од постављених програмско-политичких циљева не буде испуњен и да промену правно-политичког положаја Срба у Угарској не доживи њихова политичка генерација. ${ }^{73}$ Да би се

\footnotetext{
69 Александар Сандић је предлагао да то буде Омладинска заједница, Лаза Костић је желео назив Омладина, а Владимир Јовановић је однео превагу са предлогом Млада Србадија. Овај лист је излазио у Новом Саду и Београду од 1870 до 1872, у великом тиражу од приближно 2000 примерака.

${ }^{70}$ Устав Уједињене омладине је усвојен на трећој омладинској скупштини.

${ }^{71}$ Пола године после формалног, програмског конституисања Српске народне слободоумне странке.

72 3. Ђере, Прилог проучавању закона о равноправности народности из 1868, Истраживања 14, Нови Сад 1992, 63-77.

73 Д. Микавица, Српско питање на Угарском сабору 1690-1918, 179-268.
} 
постигли што бољи резултати, писао је Милетић, „треба у првом реду да се сложимо, да личне односе, пријатељске одношаје наспрам наши противника, замерања и слабости одбацимо, а да обгрлимо одушевљено и својски искрени рад, само оном се одазивајући, у ком је очеличено поштење и чија је прошлост светла". Повољан исход на предстојећим изборима очекивао је ослањајући се првенствено на „пробуђену свест и патриотизам народни". Износећи мисао о оснивању Странке, у Застави 31. децембра 1868. уочи одржавања избора за Угарски сабор, Милетић је истакао да није сасвим задовољан дотадашњим посланичким радом његових сабораца и да је неопходно посланике обавезати на одговорније и преданије политичко деловање у складу са прецизно дефинисаним програмом. Страначки програм намеравао је да изнесе пред јавност на конференцији и она је сазвана за 28. јануар 1869. у Великом Бечекереку. ${ }^{74}$ Милетићу и његовим присталицама тек је предстојала дуготрајна и крајње неизвесна борба у којој се показала сва чврстина мађарских институција и непопустљивост мађарских државника и политичара према сваком чину, предлогу и захтеву који би на било који начин могао територијални интегритет и државни суверенитет Угарске довести у питање.

Извори и литература:

Az 1861-dik évi april 2-ikara hirdetett orszaggyulés képviselohazanak naploja, I-II, Pest 1861.

Бешлин, Бранко, Европски утииаји на српски либерализам, Нови Сад 2005.

Васин, Горан, Национално-политичка борба Срба у Угарској 1848-1884, Истраживања, Нови Сад 2010.

Гавриловић, Владан, Дипломатички списи код Срба у Хабзбуршкој монархији и Карловачкој митрополији од краја XVII до средине ХIХ века, Ветерник 2001.

Гавриловић, Владан, Темишварски сабор и Илирска дворска канщеларија 1790-1792, Нови Сад 2005.

Гавриловић, Славко, Политичка борба за Српску Војводину у Аустријској иаревини 18481918, зборник радова Српски покрет у револуцији 1848-1849, Нови Сад 2000.

Грујић, Н., Автобиографија, Ср. Карловци 1907.

Ђере, Золтан, Прилог проучаваюу закона о равноправности народности из 1868, Истраживања 14, Нови Сад 1992.

Ковачевић, Душко М., Јаков Игъатовић, Београд 2006.

Ковачевић, Душко М., Светозар Милетић, живот и политика, Београд 2009.

Ковачек, Б., Јован Ђорђевић, Нови Сад 1964.

Ковачек, Б., Текелијанумске историје, Нови Сад 1997.

Кондратјева, В. Н., Уједињена омладина српска 1860-1875, грађа из совјетских архива, Нови Сад 1977.

Крестић, Василије, Историја српске штампе у Угарској 1791-1914, Нови Сад 1980.

${ }^{74}$ С. Милетић, Сабрани списи, књ. 2/2, 17-18. 
Лебл, А., Омладина и српско питаање у пештанском Парламенту 1867-1871, зборник радова Уједињена омладина српска, Нови Сад 1968.

Микавица, Дејан, Политичка идеологија Светозара Милетића, Нови Сад 2006.

Микавица, Дејан, Михаило Полит Десанчић, вођа српских либерала у Аустроугарској, Нови Сад 2007.

Микавица, Дејан, Српско питање на Угарском сабору 1690-1918, Нови Сад 2011.

Микавица, Дејан, Лаза Костић, политичка биографија, Нови Сад 2011.

Микавица, Дејан, Гавриловић Владан, Васин Горан, Знаменита документа за историју Срба 1538-1918, Нови Сад 2007.

Пал, Тибор, Мађарска политичка јавност и српско питање на Балкану 1860-1878, Нови Сад 2001.

Петровић, Н., Светозар Милетић и Народна странка, књ. 1, Сремски Карловци 1968.

Mikó, Imre, Nemzetisegi jog nemzetisegi politika, Kolozsvár 1994.

Милетић, Светозар, Сабрани списи, књ. 1-3, Београд 1999-2001.

Милисавац, Ж., Историја Матиие српске 1826-1864, књ. 1, Нови Сад 1986

Полит Десанчић, Михајло, Све досадашње беседе, књ. 1, Нови Сад 1889.

Скерлић, Ј., Омладина и њена књижевност 1848-1871, Београд 1925.

Суботић, Ј., Автобиографија, књ. 5, Нови Сад 1910.

Суботић, Ј., Автобиографија, трећи део: Лето, Нови Сад 2009.

Томандл, М., Светислав Касапиновић, Панчево 1940. 


\title{
DEJAN MIKAVICA
}

\section{MILETIĆ'S SUPPORTERS ON THE WAY TO ESTABLISH THE PARTY 1860-1869}

\begin{abstract}
Summary
The supporters and followers of the Miletić's ideology sought to strengthen the preconditions for achieving national and democratic goals of the Serbian people in the Habsburg Monarchy within different youth, cultural-educational and national-political associations, institutions and organizations in the nine-year period of renewed political life (1860 - 1869). Versatile recognizing the achievements of European liberal movements, the Miletić's followers managed to define the Serbian national politics in a progressive, liberal-democratic way, after the abolition of the absolutist regime, thus increasing the chances of a comprehensive social and spiritual rebirth of the people whom they represented. Fighting against the ruling doctrine of political inequality of citizens and nations in the broader area of Hungary, they failed to provide support and alliance of Hungarian and Croatian liberals, while their confrontation with the conservative-clerical representatives of the ecclesiastical hierarchy was intensified in the field of Serbian religious and educational autonomy. Nevertheless, they progressively influenced all the spheres of social life of Prečani Serbs, contributed to the establishment and activities of the United Serbian Youth, and finally, established a political party which goal was to represent the interests of all Serbs in Austria-Hungary.
\end{abstract}

Keywords: Svetozar Miletić, Unified Serbian Youth, Hungarian Parliament, Serbian Church-National Parliament, Serbs, Croats, Hungarians, Vojvodina 